University of Michigan Law School

University of Michigan Law School Scholarship Repository

1922

\title{
Basis of Relief from Penalties and Forfeitures
}

\section{Edgar N. Durfee}

University of Michigan Law School

Available at: https://repository.law.umich.edu/articles/1231

Follow this and additional works at: https://repository.law.umich.edu/articles

Part of the Legal Remedies Commons, and the Property Law and Real Estate Commons

\section{Recommended Citation}

Durfee, Edgar N. "Basis of Relief from Penalties and Forfeitures." Mich. L. Rev. 20 (1922): 646-9.

This Response or Comment is brought to you for free and open access by the Faculty Scholarship at University of Michigan Law School Scholarship Repository. It has been accepted for inclusion in Articles by an authorized administrator of University of Michigan Law School Scholarship Repository. For more information, please contact mlaw.repository@umich.edu. 


\section{Michigan LaW REVIEW}

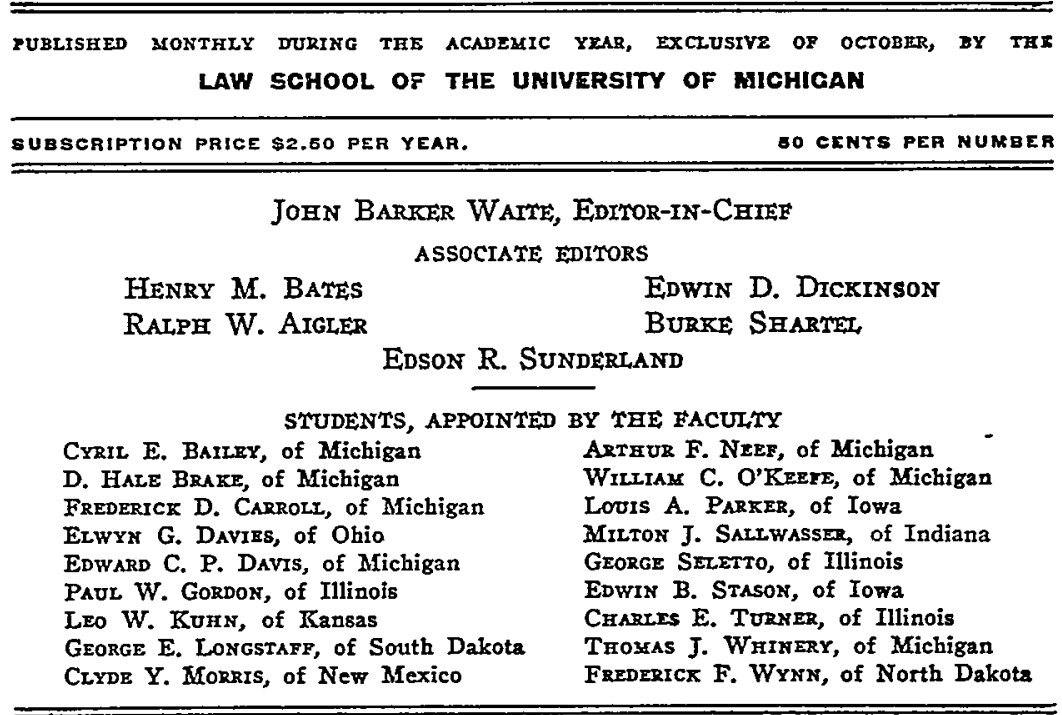

\section{NOTE AND COMMEN'T}

The Basis of Relief from Penatites and Forfetrures.-The equitable principle of relief from penalties and forfeitures is so far elementary as almost to defy analysis. Many, perhaps most, of the judicial explanations of the principle have based it upon interpretation or construction, appealing to the doctrine that equity regards intent rather than form. Yet a logical application of this doctrine would lead to sesults very different from those which have actually been arrived at in the decisions. Thus, a stipulation in a mortgage that the mortgagor waives his equity of redemption can hardly be interpreted as meaning that he does not waive it, yet all such stipulations are ignored and redemption granted, nevertheless. Again, a penalty for breach of contract cannot be saved by the most solemn - declaration that it is intended as liquidated damages. It must be conceded that many cases have actually been decided on the interpretation theory, producing such enormities as Iowra Land Co. v. Mickel, 4I Ia. 402 (sale of land, \$15a out of $\$ 600$ paid, $\$ 4000$ in improvements, second instalment of $\$ 150$ one day late due to a misunderstanding; held forfeited), and Doctorman v. Schroeder, II4 Atl. 81o (N. J., I92I; sale of land, \$1000 paid, last instalment of $\$ 1000$ thirty minutes late; held forfeited). But such cases represent the minority view, 
and one applicable only to instalment sales, no court pursuing this course in mortgage or liquidated damage cases.

In truth, relief from penalties and forfeitures involves a nullification of the intent of the parties, a refusal to give legal effect to their solemn agreements, and constitutes a glaring exception (not, of course, the only one) to the general rule that parties of full capacity are bound by their agreements. And this exception must be referred to "conscience," the principle of natural justice upon which equity has relieved from a great variety of unconscionable transactions, and with which, more recently, the common law has fallen in love.

But we have only cleared the ground when we have referred the problem to the head of conscience, for conscience embraces a multitude of principles. Can we identify more precisely the principles governing relief from forfeiture? Analyzing the Chancellor's conscience may be unscrewing the inscrutable, but let us press on.

It has been suggested by high authority that equitable interference in the mortgage case is based upon duress of circumstances. "Necessitous men are not free men." Vernon v. Bethell, 2 Eden Iro. "Debtors, under the force of pressing necessities, will submit to almost any exactions." Pierce v. Robinson, 13 Cal. 116, I26.

But this will not explain relief from the stipulation for forfeiture in a land contract, nor relief of the lessee from forfeiture for non-payment of rent, nor relief from penalty for breach of an ordinary contract. Cases of this sort may indeed occur in which the party submitting himself to forfeiture does so because of pressing necessity, just as cases may occur in which a mortgagor is not under such pressure, but this element may be considered normal in the mortgage cases and abnormal in the others. What is typical of these last is an element of misreliance. It is not mistake of present fact, and therefore not mistake in the technical legal sense. It is mistake or error as to future developments. Yet it is a mistake which all mankind is prone to make, that of overconfidence in one's own capacities and faith in a special providence. Hope springs eternal. For this all thanks, but it leads us to over-sanguine commitments. This being human nature, the courts cannot but take account of it and relieve from its consequences, so far as this can be done without undue invasion of other interests. That this is the basic principle in these cases seems to be borne out by the fact that the judicial attitude toward an agreement for "liquidated damages" is so different from that toward an accord. An agreement to pay "liquidated damages" for a future breach of contract will not be enforced unless it bears a reasonable relation to actual damage. WILLISTON, ConTRACrs, $\$ \$$ 777-779. But an accord after breach can only be impeached for duress or fraud or mistake (in the ordinary sense of those terms), and even mistake will be unavailing if the accord involves a settlement of a dispute upon the very matter which is mistaken. $I b$., $\$ \S 780$, I543. Again, a surrender by a defaulting lessee or purchaser is on a very different footing from forfeiture 
by proviso in the lease or contract. Do not these distinctions turn upon the presence or absence of misreliance upon airy hope?

And the element of misreliance is present in the typical mortgage case. That it has been a vital element is borne out by the state of the cases. Stipulations providing for future forfeiture of the equity of redemption, if the debt is not paid at a certain day, are held absolutely void. But when the mortgagor by present conveyance releases his equity of redemption to the mortgagee, the transaction is not necessarily void, the most liberal doctrine being that it will be scrutinized in much the same way as transactions between trustee and cestubi que trust, to see that no undue advantage is taken of the necessities of the mortgagor. Yet the mortgagor is, presumably, at least as necessitous in the latter case as in the former. It has been said that the distinction is between stipulations contemporaneous with the mortgage and those subsequent to it. 2I HARv. I. REv. 466. But in the few cases involving subsequent agreements for future forfeiture, the transaction has, by all but unanimous authority, been held absolutely void. Batty v. Snook, 5 Mich. 23I; Holden Co. v. Interstate Co., 87 Kas. 22I ; Cohn v. Bridgeport Co., Ir5 Atl. 328 (Conn., 192x). Contra, Bradbury v. Davenport, 120 Cal. 152 . It would seem that the distinctions among the mortgage cases turn upon the presence or absence of the mirage of hope.

Yet, it can hardly be said that the other element, duress of circumstances, is not material in the mortgage cases. There is nothing else to support the "scrutiny" of the release (by present conveyance) of the equity of redemption. Furthermore, the fixed rule of mortgage law by virtue of which all executory stipulations waiving the equity of redemption are void, regardless of the equities of the particular case, stands in marked contrast to the doctrines of the other cases under discussion, which (characteristic in this respect of equity at large) are flexible and take account of the particular circumstances. Would it not seem that this might be explained by the fact that in the former the elements of duress and misreliance combine, while in the latter only one of these elements appears? Justice Field said of the former rule: "Its maintenance is deemed essential to the protection of the debtor, who, under pressing necessities, will often submit to ruinous conditions, expecting or hoping to be able to repay the loan at its maturity." Pengh v. Davis, 96 U. S. 332. (Italics ours.)

Of course, the rigid rule of mortgage law serves the social interest in legal certainty, but this interest would be likewise served by a like rigid rule in the other cases. This interest being substantially constant throughout, and the results being diverse, it would seem that this social interest has not controlled. Eliminating that, there is left, on the one side, the "equity" of duress or misreliance (or both in combination), and on the other side and opposed to them, the social and individual interests in freedom of contract and security of transactions, plus (especially in the liquidated damage cases) a social interest in settlement by private agreement of questions which would otherwise present a judicial problem of considerable difficulty. And in this struggle of conflicting interests it would seem that, when duress of circum- 
stance and mistaken self-confidence combine they have won complete recognition in a rigid rule of nullification, while either of these elements standing alone has won but partial recognition, in the rule of particular equities.

It must be conceded that the problems herein discussed are somewhat more complex than this analysis would indicate. There are elements in them other than those discussed. See the article on "Penalties and Forfeitures," by William H. Lloyd, in 29 HARv. L. REv. II7. And there are certain features of the law which seem not to fit into the scheme at all. For example, the transactions which, upon lines of distinction none too well settled (see the little note of some six hundred pages in L. R. A. I9I6 B, I8 ff.), are held to be conditional sales rather than equitable mortgages, these always involve the fool's paradise, and very often involve duress of circumstance, yet the letter of the agreement is enforced. And we only partially remove the inconsistency when we say that substantially all the hard cases are taken care of by throwing them, on one ground or another, into the mortgage category. All these difficulties are admitted, yet it is hoped that the foregoing analysis throws a little light into a dark corner. E. N. D. 